sciendo Порівняльна професійна педагогіка 9(3)/2019 Comparative Professional Pedagogy 9(3)/2019

DOI: $10.2478 /$ rpp-2019-0024

$\mathrm{PhD}$ in Pedagogy, Head of the Navigation and Ship Control Department,

OLEKSANDR DANYLENKO

Danube Institute of "Odessa Maritime Academy" National University Address: 9 Fanagoria St., Ismail, Odessa region, 68601, Ukraine E-mail: obdan@i.ua

\title{
FORMING READINESS IN FUTURE NAVIGATORS FOR PROFESSIONAL ACTIVITY IN MARITIME UNIVERSITIES OF GREAT BRITAIN
}

\begin{abstract}
The article is devoted to the problem on training of maritime specialists in universities of Great Britain; in particular, it is a question of training navigators. It was noted that there are dozens of maritime educational institutions and a long tradition of training maritime specialists in the country. The system of maritime education in the United Kingdom is effective, and the level of training of specialists, including navigators, allows them to qualitatively perform their official duties on ships, which, in its turn, guarantees the safety of navigation. The peculiarity of professional training of navigators is that the educational program is focused on practical activities in accordance with the requirements of the rules of the International Convention on the Training and Certification of Seafarers, recommendations of the International Maritime Organization and other regulatory documents. It was found out that the UK Nautical Institute is working on the continuous improvement of the educational level of specialists operating maritime vessels. The article also discusses the training of navigators at the Maritime Centre of the University of London and at the University of Plymouth. The training of navigators on simulators is considered as a type of practical training and is conducted in accordance with national and international requirements for a computer simulator complex and software training complexes. The author of the article draws attention to the sufficient number of modern simulators, training equipment and laboratories, which are used to work out practical skills of future navigators. It has also been clarified that in all UK maritime higher education institutions the mandatory condition for successful completion of training is the completion of maritime professional practice. The number of hours for such practices is determined by the relevant regulations. The high ranking of British maritime education institutions attracts students from around the world. For international students there are comfortable conditions for admission, study and residence. They can improve their English language skills and take preparatory courses for admission.

Keywords: educational institutions, future navigators, simulators, training equipment, maritime professional practice, relevant regulations, training, practical activities.
\end{abstract}

\section{АНОТАЦІЯ}

Стаття присвячена проблемі підготовки морських фахівиів в університетах Великої Британії; зокрема, мова йде про підготовку судноводїв. У краӥні діють десятки морських навчальних закладів та давні традиції підготовки фахівиів морської справи. Система морської освіти у Великій Британії є ефективною, а рівень підготовки фахівиів, зокрема судноводіїв, дозволяе їм якісно виконувати посадові обов'язки на кораблях, що, у свою чергу, гарантує безпеку мореплавства. Особливістю професійної підготовки судноводіїв є те, що освітня програма орієнтована на практичну діяльність у відповідності до вимог правил Міжнародної конвенщії про підготовку 
та дипломування моряків, рекомендацій Міжнародної морської організації та інших регламентуючих документів. 3'ясовано, щзо Морський університет Великої Британії працює над постійним підвищенням освітнього рівня фахівців, які керують морськими суднами. У статті також розглядається підготовка судноводїв у Морському иентрі Лондонського університету та в Університеті Плімута. Тренажерна підготовка судноводіїв розглядається як вид практичної підготовки $i$ проводиться $у$ відповідності до національних та міжнародних вимог на апаратно-програмних тренажерних комплексах. Автор статті звертає увагу на наявність достатньої кількості навчального обладнання - сучасних симуляторів, тренажерів та лабораторій, які використовуються для відпрацювання практичних навичок майбутніх судноводіїв. Окрім того також з'ясовано, щуо в усіх морських закладах освіти Великої Британії обов'язковою умовою успішного завершення навчання $\epsilon$ проходження плавальної практики, кількість годин якої визначається відповідними регламентуючими документами. Високий рейтинг британських морських закладів освіти приваблює студентів 3 різних країн світу. Для іноземних студентів створено комфортні умови для вступу, навчання та проживання. Іноземні студенти можуть покращити знання англійської мови та пройти підготовчі курси для вступу.

Ключові слова: заклади освіти, майбутні судноводї, тренажери, симулятори, плавальна практика, дипломування, підготовка, практична діяльність.

\section{INTRODUCTION}

The beginning of the new millennium marked the world economic system's entry into a qualitatively new stage of transformation, which touched all spheres of human activity, including international trade. The globalization of international trade implies the free movement of resources and goods to all parts of the world, which is not possible without the use of maritime transport, which is the basis for the development of national and international markets. The efficiency of shipping is directly related to the quality of training of specialists for this sphere of economy. Globalization of quality requirements for maritime education, as defined at the level of the International Maritime Organization (IMO), also aims to improve the approach to the educational process in the leading maritime profession - the profession of the navigator.

\section{THE AIM OF THE STUDY}

Thus, the purpose of the article is to generalize the experience of professional training of navigators at maritime universities of Great Britain, focused on the permanent improvement of navigation safety.

\section{THEORETICAL FRAMEWORK AND RESEARCH METHODS}

The problem of training of navigators has been and remains relevant. Scientific researches in this field are carried out with the purpose of improvement of quality of maritime education and ensuring safety of navigation (Guides, \& Jepson, 2013; Bow, 2002). Thus, S. Voloshynov (2012) substantiates the peculiarities of applying a systematic approach to the algorithmic training of navigators in the information and communication environment; M. Musorina (2016) studies the formation of technical competence of future navigation specialists in the process of studying technical disciplines; L. Herhanov (2016) presents the conceptual framework for professional training of qualified seafarers at the workplace. The process of training maritime specialists in the UK has not yet been sufficiently studied by educational science, but some peculiarities of training are to some extent revealed in the works of T. Kobzeva \& I. Dehtiarenko (2016). 
The study of the theoretical aspect of the problem implied the use of a whole complex of theoretical methods, namely, explanatory and analytical method using the analysis and synthesis of scientific research on the preparation of navigators; methods of generalization and systematization - to highlight the features of professional training of navigators in educational institutions of Great Britain and formulate the appropriate conclusions.

\section{RESULTS}

World shipping is fairly considered to be the basis of the global trade. According to the International Maritime Organization (IMO), more than 90 per cent of all foreign trade cargo is transported by sea. Thanks to the hard work of 1.5 million seafarers, 6.5 billion of the world's inhabitants have the opportunity to get the necessary amount of food and energy resources (Mitropoulos, 2010, p. 5). According to the UN Conference on Trade and Development at the beginning of 2010, the world merchant fleet consisted of 102194 vessels with a total deadweight of 1276137 thousand tons (Review of Maritime Transport, 2010). A significant number of vessels are serviced by specialists who have been trained in maritime education institutions of Great Britain.

The historical background and geographical location of Great Britain has contributed to the emergence of Great Britain as one of the leading maritime countries in the world. In England in the middle of the 16th century, the economic and political situation and internal development helped to transform the country into a maritime power, and in the second half of the XVI century the British made decisive steps in this direction. The British Isles for a long time were on the edge of the world, at the tip of Europe, but after the Great Discoveries they became the starting point of voyages to new worlds (Brodel, 1992). It should be noted that since the United Kingdom is an island country, more than 70 international commercial seaports and more than 200 small port points (where the transportation of local cargo is handled) have been set up in the country for servicing merchant and passenger ships and cargo handling. Up to 30 million passengers are shipped through British ports annually. It should also be noted that London is home to the headquarters of the International Maritime Organization (IMO), and to the representative offices of more than 120 ship-owners around the world. There are also leading maritime register companies, in particular, Lloyd's Register in Shipping, the oldest and second largest classification society in the world (after the Japanese Society Class NK), which registered up to $20 \%$ of the world's merchant marine fleet tonnage (Kobzeva, \& Dehtiarenko, 2016).

The development of seafaring and shipbuilding in Britain in the 16th century led to the establishment of maritime educational institutions. Thus, in 1972, the Nautical Institute (NI) was established. The main role of the NI is to ensure the highest possible professional focus aimed at improving the educational level of maritime industry professionals involved in the process of ship handling. Today the Institute retains the status of an international maritime professional center, which is working on many projects, the main purpose of which is to improve the state of shipping, to ensure the safety of navigation. These include Electronic Navigation and Ice Shipping (NI - Nautical Institute, 2017). The introduction of electronic navigation is the main initiative of the International Maritime Organization to harmonize and strengthen navigation systems, the implementation of which will have a significant impact on the future of maritime navigation. There is a clear and urgent need to provide ship masters and all those responsible for the safety of navigation with modern, proven tools to make maritime navigation and communication more reliable and convenient, thereby reducing the number of errors. If to use technological advances without proper coordination, there is a risk that further development of marine navigation systems 
will be hampered by a lack of standardization on board and ashore, incompatibility between ships, and an excessive level of complexity. The Ice Shipping project aims to contribute to the accreditation of ice navigation training and to recognize the certification standards of special skills, knowledge and competence to bridge watch officers, necessary for the safe handling of ships in ice conditions. Seafarers should be aware of the physical properties of the ice, the power and maneuverability of the ship in the ice, the different approaches used in the passage planning process and the human factor associated with cold weather. Even the possibility of ice being present during the passage can cause delays, route changes or, if not handled properly, damage to the vessel.

Nautical Institute, as the leading international professional organization for sea professionals, is fully involved in the process of identifying users' needs and is continuously working at facilitating their implementation. The Institute has been working in cooperation with other organizations, with the support of its committees, national branches and the Ship Reporting Group.

London John Moores University (LJMU) of is a well-known institution where one can obtain one of the maritime occupations, including the profession of navigator. It is a public research university that dates back to 1823, when the Liverpool Mechanics' School of Arts was founded. It was awarded the title of John Moores University of Liverpool in 1992 by a special act of Parliament. More than 20,000 students study for getting Bachelor's, Master's and Doctoral Degrees. LJMU is a member of the British University Missionary Group and the European University Association. The University regularly ranks high in European and world rankings on a wide variety of indicators. A large number of courses and specializations are included in the educational programs of various faculties of the university.

To meet the needs of the maritime industry there was established Maritime Centre of LJMU (LJMU, 2019). Now it offers a full range of courses under the International Convention on Standards of Training, Certification and Watchkeeping for Seafarers (STCW). The Centre also offers foundation degrees, Chief Mate and Master Courses and bespoke training. The courses are held all year round and include specializations in all aspects of maritime transport, from management to medical care and fire safety. Over the years, the centre has trained a large number of marine specialists, deck officers and naval engineers. For practical training, the university provides unique laboratories, training equipment, various simulators and a complete simulation model of the ship. As in any educational institution where marine specialists and navigators are trained, the Marine Center of the University has ECDIS and GMDSS complexes. ECDIS is equipped with 10 stations and is a complete desktop simulation solution for navigation training. Additional facilities similar to the ECDISS suite include LICOS (Liquids Simulator) and GMDSS (Global Maritime Distress and Safety System) equipment. To ensure quality training for navigators, the Center has bridge simulators that allow sea pilots, captains and senior navigators to develop and practice the necessary skills in a realistic, geographically accurate virtual, but risk-free environment. On one of the ship's eight bridges, they learn how to act as they would in the real world on the high seas. Each bridge is equipped with the latest electronic navigation devices such as Radar, ECDIS, GPS, Loran and AIS. When these tools are combined with a fully functional GMDSS communication system, the bridges become absolutely realistic.

The University provides an opportunity for international students to receive education. There are a number of training programs for those wishing to enter the University. It is standard and advanced training for Bachelor's degree (International Foundation Year, Extended International Foundation Year), Standard and extended International Year 
(International Year One, Extended International Year One), and preparation for the master's degree (Pre-Masters). To participate in the programs it is necessary to correspond to the certain levels of academic knowledge and the English language. If the language level is insufficient, one can first take special English language training courses (LJMU, 2019).

The University of Liverpool has a unique model of higher education that emphasizes onthe-job training and the development of various skills of its graduates as well as effective cooperation with the employer.

The University of Plymouth in Great Britain is among the many educational institutions that train marine specialists, in particular navigators. The School of Engineering of the Faculty of Science and Engineering provides training in three main areas, including Navigation and Marine Sciences (University of Plymouth, 2019).

As at the Marine Centre of the University of Liverpool, those wishing to enrol first take a preparatory course - FdSc (Foundation Science). The course program consists of specialty disciplines and academic English. After successful completion of the course, one can move on to the faculty they would like to study at.

Each undergraduate course taught at a university has a corresponding document (curriculum) describing the objectives and structure of the course, teaching and learning methods, learning outcomes and assessment rules. Once approved by the University, the programme is submitted for accreditation by the Maritime and Coast Guard Agency through approval by the Merchant Marine Training Board.

The university offers two ways to study. The first is accredited by the Merchant Marine Training Authority - training of watch officers (without categories) - Bachelor (with honors). This way is designed for those who want to become a professional watch officer.

The second one is not accredited by the Merchant Marine Training Administration. This type of training is designed for those who do not want to go out to sea and work in the field, but can work in the management or administration of the offshore industry on land. The modules of this training option are the same as of the first one, and the year of work experience can be held in any sector of the maritime industry.

The university studies last four years. During the first year, students learn the basics of maritime operations, meteorology and navigation technology, including the use of a ship's simulator and sailing training vessel, and acquire skills in navigation, leadership and management directly at sea while there for a week, and those students who receive sponsorship spend the whole summer at sea after their first year at the university. In the second year of study, students will improve their navigation skills and learn about the positioning (including celestial navigation), the structure and stability of the ship and cargo operations. Future navigators also get acquainted with the latest satellite positioning and synchronization systems. A week devoted to sailing on the high seas helps to apply the skills of navigation, leadership and management in practice, adapting theoretical knowledge to the local environment, i.e. applying it in practice. After a second year of training, students have a possibility to spend a year on the high seas or work on land in the maritime industry. This year is not obligatory. In the event of having a qualification or wishing to build a career ashore, one can immediately move on to the final year of study.

During the final year of training, future navigators will study current topics of navigation management and complete a one-year research project on the chosen subject. They have the opportunity to work on the project and be represented at a professional conference attended by leading maritime industry players. The result of the years of studying is a Bachelor's degree in Navigation and Marine Science (with honor). 


\section{CONCLUSIONS}

Today about $90 \%$ of all goods and $95 \%$ of goods of Great Britain are being shipped by the world ocean. Despite the rapid development of land and air transport, maritime transport is as important for the local and global economy as it was when the first maritime school was founded. In this context, the quality training of those who help to carry out such transportations and make shipping safe is of the utmost importance. Many years of experience in training navigators in the UK can be used in the Ukrainian maritime education system, and therefore further study of foreign educational programs, organization of practices and control activities is promising.

Every year, the training and material base for the preparation of future navigators is updated and improved. In the light of total computerization and digitalization, we consider the prospects of further research to be the study of the results of wide application of the latest achievements of scientific and technical progress in the educational process.

\section{REFERENCES}

1. Bow, S. (2002). Working on cruise ships. London: Vacation Work.

2. Brodel, F. (1992). Materialnaya tsivilizatsiya, ekonomika i kapitalizm, XVXVIII vv. Moskva: Vremya mira.

3. Guides, R., \& Jepson, T. (2013). The Maritime provinces Rough Guides snapshot Canada (includes Nova Scotia, Cape Breton Island, New Brunswick and Prince Edward Island). London: Rough Guides.

4. Herhanov, L. (2016). Teoretychni i metodychni zasady profesiinoi pidhotovky kvalifikovanykh robitnykiv morskoho transportu na vyrobnytstvi. (Dys. d-ra ped. nauk). Instytut profesiino-tekhnichnoi osvity, Kyiv.

5. Kobzeva, T., \& Dehtiarenko, I. (2016). Vliianie globalizatsii na effektivnost gruzoperevozok morskim transportom Velikobritanii. Materialy III Mezhdunarodnoy nauchnoy konferentsii "Innovatsionnaia ekonomika". Kazan: Buk.

6. LJMU. (2019). Faculty of Engineering and Technology: Maritime Centre Retrieved from https://www.ljmu.ac.uk/about-us/faculties/faculty-of-engineering-and-technology/ maritime-centre/facilities.

7. Mitropoulos, E. E. (2010). A message to the world's seafarers. IMO News, 1, 5.

8. Musorina, M. (2018). Formuvannia tekhnichnoi kompetentnosti maibutnikh fakhivtsiv sudnovodinnia u protsesi navchannia tekhnichnykh dystsyplin. (Dys. kand. ped. nauk). Natsionalnyi pedahohichnyi universytet imeni M. P. Drahomanova, Kyiv.

9. NI - Nautical Institute. (2019). Retrieved from http://мимо.com.ua/info/19-ninautical-institute-morskoy-institut-velikobritanii-miv.html.

10. Review of Maritime Transport. (2010). Retrieved from https://unctad.org/en/ Docs/rmt2010 en.pdf.

11. University of Plymouth. (2019). Undergraduate: BSc (Hons) Navigation and Maritime Science. Retrieved from https://www.plymouth.ac.uk/courses/undergraduate/bscnavigation-and-maritime-science.

12. Voloshynov, S. (2012). Alhorytmichna pidhotovka maibutnikh sudnovodiiv z systemoiu vizualnoi pidtrymky $v$ umovakh informatsiino-komunikatsiinoho pedahohichnoho seredovyshcha. (Dys. kand. ped. nauk). Khersonskyi Derzhavnyi Universytet, Kherson. 